\title{
The Presence of Two Complete Homologous meta Pathway Operons on TOL Plasmid pWW53
}

\author{
By DAVID J. OSBORNE, $\dagger$ ROGER W. PICKUP \\ AND PETER A. WILLIAMS* \\ Department of Biochemistry, School of Biological Sciences, University College of North Wales, \\ Bangor, Gwynedd LL57 2UW, UK
}

(Received 11 April 1988; revised 14 July 1988)

\begin{abstract}
pWW53 is a $110 \mathrm{kbp}$ catabolic plasmid which encodes the complete pathway for the utilization of toluene and the xylenes. The upper pathway operon $x y l C A B$ is located between two homologous but distinct meta pathway operons, $x y l D L E G F(I, J, K) H$, which are in direct repeat. These have each been cloned on large HindIII restriction fragments HA $(17.5 \mathrm{kbp})$ and HB $(15.6 \mathrm{kbp})$, the restriction sites of which have been mapped. During growth of MT53 on benzoate, mutants which have lost the ability to grow on hydrocarbons such as $m$-xylene $\left(\mathrm{Mxy}^{-}\right)$ but which retain the ability to grow on their carboxylic acid metabolites such as $m$-toluate $\left(\mathrm{Mtol}^{+}\right)$take over the culture before ultimately being displaced by plasmid-free strains which are $\mathrm{Mxy}^{-} \mathrm{Mtol}^{-}$. The plasmids in the $\mathrm{Mxy}^{-} \mathrm{Mtol}^{+}$mutants are formed by a large deletion between homologous regions of the two duplicate meta pathway operons. This causes the loss of the intervening $x y l C A B$ operon and the formation of a hybrid $x y l D L E G F(I, J, K) H$ operon, starting with the genes originally on HA and terminating with the genes originally on HB.
\end{abstract}

\section{INTRODUCTION}

The pathway for catabolism of toluene and some substituted toluenes, such as $m$-xylene, in Pseudomonas appears to be almost always plasmid determined (Fig. 1). A number of these TOL plasmids have been reported (Williams \& Worsey, 1976; Yano \& Nishi, 1980; Kunz \& Chapman, 1981) but in only three cases have the locations and the physical organization of the catabolic genes been determined. The archetypal plasmid pWW0 (Worsey \& Williams, 1975) and its cointegrate with RP4, pTN2 (Nakazawa et al., 1978), have been the subjects of the most intense investigations but, more recently, two other TOL plasmids have been analysed. In both cases the analysis has been facilitated by the use of cointegrate plasmids formed spontaneously by the insertion into the RP4 replicon of a length of the TOL plasmid DNA carrying the catabolic genes. Both pWW53-4, derived from pWW53 (Keil et al., 1985a, 1987), and pDK2, from pDK1 (Shaw \& Williams, 1988), carry on the TOL plasmid insert the genes of the complete pathway, comprising the upper pathway operon $x y l C A B$ and the meta pathway operon $x y l D L E G F(I, J, K) H$ together with regulatory genes.

Further investigation of pWW53 was prompted by the apparently anomalous restriction fragment patterns of the plasmids in two spontaneous deletion mutants which were found after the host strain Pseudomonas putida MT53 was grown in benzoate. Analysis of these plasmids and of the original wild-type plasmid showed that pWW53 carries two homologous, but distinguishable, direct repeats of the meta pathway operon $x y l D L E G F(I, J, K) H$. The deletion mutants were the result of homologous recombination between the duplicate copies, generating large deletions of the intervening DNA and the formation of new hybrid operons.

+ Present address: PHLS, NCTC, Plasmid Section, 61 Colindale Avenue, London NW9 5HT, UK.

$\ddagger$ Present address: Freshwater Biological Association, Windermere Laboratory, Ambleside, Cumbria LL22 OLP, UK. 


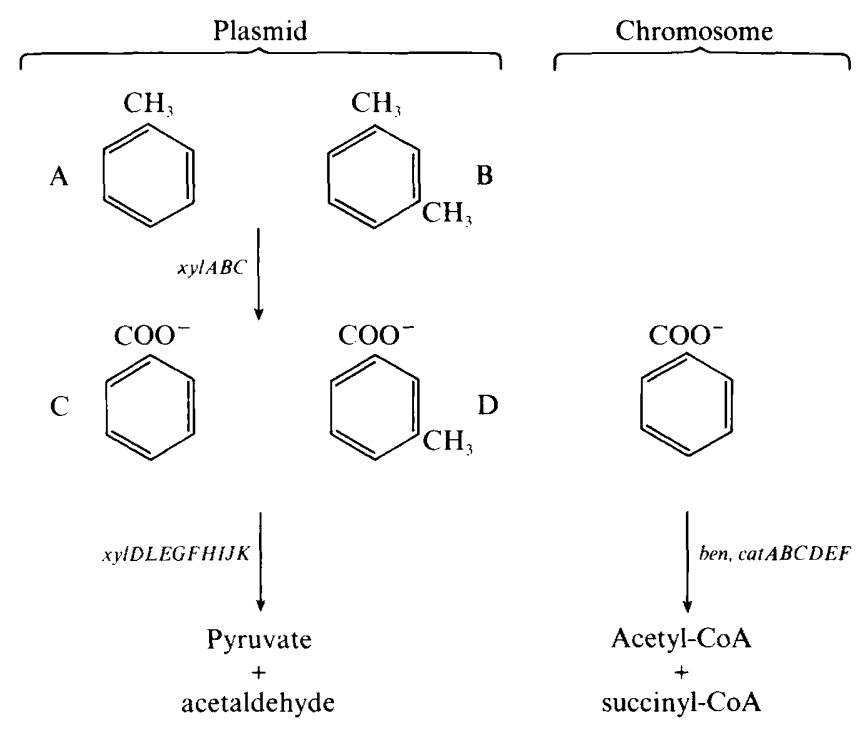

Fig. 1. Plasmid- and chromosome-determined pathways for the catabolism of toluene (A), $m$-xylene (B), benzoate (C) and $m$-toluate (D) by Pseudomonas putida MT53.

\section{METHODS}

Bacterial strains and plasmids. The Escherichia coli and Pseudomonas putida strains and the plasmids used or constructed are listed in Table 1.

Media and culture conditions. Bacteria were grown and maintained as described by Worsey \& Williams (1975) and Keil et al. $(1985 a, b)$. P. putida strains carrying the deleted plasmids were maintained on minimal agar plates with $5 \mathrm{~mm}-m$-toluate. For enzyme assay, uninduced $E$. coli were grown on Luria broth and uninduced $P$. putida on $10 \mathrm{~mm}$-acetate-minimal medium. Induction by $m$-toluate was achieved by adding $5 \mathrm{~mm}$ - $m$-toluate to $P$. putida cultures which had been growing on $10 \mathrm{~mm}$-acetate for $6-8 \mathrm{~h}$ and harvesting the cultures $12-15 \mathrm{~h}$ later when stationary phase was reached.

Selection of mutants during growth on benzoate. Strain MT53 was grown on 5 mM-benzoate in sequential batch cultures as described by Williams et al. (1988). Selection experiments were also done in a simple chemostat made of a round-bottomed flask with siphon overflow into which $5 \mathrm{~mm}$-benzoate in minimal salts medium was pumped at a dilution rate of $0 \cdot 1-0 \cdot 2 \mathrm{~h}^{-1}$.

Enzyme assays. Enzymes were assayed in cell-free extracts using published procedures for catechol 2,3oxygenase and 2-hydroxymuconic semialdehyde dehydrogenase (Sala-Trepat \& Evans, 1971), for 2-hydroxymuconic semialdehyde hydrolase (Murray \& Williams, 1974) and for benzyl alcohol and benzaldehyde dehydrogenases (Worsey \& Williams, 1975). In each case a unit of activity is defined in terms of $\mu$ mol substrate converted $\min ^{-1}$.

Plasmid and DNA manipulations. pWW53, pWW53-1, pWW53-2 and pWW53-4 were extracted from Pseudomonas hosts according to Wheatcroft \& Williams (1981). Vector and recombinant plasmids, isolated from $E$. coli hosts, were recovered after $\mathrm{CsCl} /$ ethidium bromide gradient centrifugation. Hydrolyses with restriction endonucleases, DNA ligations and transformation of $E$. coli with plasmid DNA were done by standard procedures (Maniatis et al., 1982). Both E. coli and P. putida strains were screened for the presence of small plasmids according to Holmes \& Quigley (1981). DNA-DNA hybridizations were done as described by Keil \& Williams (1985) after Southern (1975).

Mobilization of recombinant plasmids into $P$. putida. Recombinant plasmids with inserts in the broad-host-range vector pK T230 were mobilized from $E$. coli into $P$. putida using the unstable RP4 derivative plasmid pNJ5000 as described by Keil et al. (1985a).

\section{RESULTS}

\section{Growth of MT53 on benzoate}

After growth on benzoate-minimal medium all $P$. putida strains containing TOL plasmids segregate characteristic mutants which either have lost the plasmid or have suffered deletions in the plasmid with total or partial loss of the catabolic genes (Bayley et al., 1977; Kunz \& Chapman, 1981; Keil \& Williams, 1985). Strain MT53 is no exception and after several 


\section{Table 1. Bacterial strains and plasmids}

\begin{tabular}{|c|c|c|}
\hline Strain & Plasmid & Notes and references \\
\hline \multicolumn{3}{|c|}{ Pseudomonas putida strains } \\
\hline MT53 & pWW53 & Wild-type $\mathrm{Mxy}^{+} \mathrm{Mtol}^{+}$(Keil et al., 1985a) \\
\hline MT53-1 & pWW53-1 & $\mathrm{Mxy}^{-} \mathrm{Mtol}^{+}$mutant of MT53, segregated during growth on benzoate (th \\
\hline MT53-2 & pWW53-2 & $\mathrm{Mxy}^{-} \mathrm{Mtol}^{+}$mutant of MT53, segregated during growth on benzoate (th \\
\hline MT53-3 & & $\begin{array}{l}\mathrm{Mxy}^{-} \mathrm{Mtol}^{-} \text {plasmid-free derivative of MT53, selected after prolonged } \mathrm{g} \\
\text { benzoate }\end{array}$ \\
\hline PaW95 & & $\begin{array}{l}\text { Plasmid-free, benzoate cis-glycol dehydrogenase }{ }^{-} \text {mutant of } P . \text { putida } \mathrm{n} \\
\text { (Keil et al., 1985a) }\end{array}$ \\
\hline PaW130 & & Rif $^{r}$ plasmid-free derivative of $P$. putida $\mathrm{mt}-2$ (Keil et al., 1985a) \\
\hline PaW611 & pWW53-4 & $\begin{array}{l}\mathrm{Mxy}^{+} \mathrm{Mtol}^{+} \mathrm{Cb}^{\mathrm{r}} \mathrm{Km}^{\mathrm{r}} \mathrm{Tc}^{\mathrm{r}} \text {. Plasmid is cointegrate between } \mathrm{pWW} 53 \text { and } \\
\text { (Keil } \text { et al., 1985a) }\end{array}$ \\
\hline \multicolumn{3}{|c|}{ Escherichia coli strains } \\
\hline CA60 & & $h s d R$ hsdM recBC derivative of $\mathrm{C} 600$ \\
\hline ED8654 & & Murray et al. (1977) \\
\hline \multicolumn{3}{|c|}{ Vectors and recombinant plasmids } \\
\hline & pKT230 & Bagdasarian et al. (1981) \\
\hline & pNJ5000 & Grinter (1983) \\
\hline & pWW53-3002 & $15.6 \mathrm{kbp}$ insert of $H$ indIII fragment $\mathrm{HB}$ from pWW53 in pKT230 \\
\hline & pWW53-3003 & $16.0 \mathrm{kbp}$ insert of novel HindIII fragment from $\mathrm{pWW} 53-1$ in $\mathrm{pKT} 230$ \\
\hline & pWW53-3004 & $15.8 \mathrm{kbp}$ insert of novel HindIII fragment from pWW53-2 in pKT230 \\
\hline & pWW53-3301 & $\begin{array}{l}17.5 \mathrm{kbp} \text { insert of } H \text { indIII fragment HA from pWW53 in pKT230 } \\
\text { (Keil et al., 1985a) }\end{array}$ \\
\hline & pWW53-3501 & $2 \cdot 1 \mathrm{kbp} X h o \mathrm{I}$ insert carrying $x y l E$ from $\mathrm{HA}$ in pKT230 \\
\hline & pWW53-3502 & $2.1 \mathrm{kbp} X h o \mathrm{I}$ insert carrying $x y l E$ from $\mathrm{HB}$ in pKT230 \\
\hline & pWW53-3504 & $2.1 \mathrm{kbp}$ XhoI insert carrying $x y l E$ from pWW53-1 in pKT230 \\
\hline & pWW53-3901 & $4.7 \mathrm{kbp} S m a \mathrm{I}$ insert carrying $x y l D L$ from HB in pKT230 \\
\hline
\end{tabular}

Table 2. Specific activity of catabolic enzymes in P. putida MT53 and its derivatives

Specific activities are expressed as milliunits (mg protein) ${ }^{-1}$. BADH, benzyl alcohol dehydrogenase; $\mathrm{BZDH}$, benzaldehyde dehydrogenase; $\mathrm{C23O}$, catechol 2,3-oxygenase; HMSH, 2-hydroxymuconic semialdehyde hydrolase; HMSD, 2-hydroxymuconic semialdehyde dehydrogenase; $\mathrm{C} 12 \mathrm{O}$, catechol 1,2-oxygenase; ND, not determined.

$\begin{array}{rlrrrrrr}\text { Strain } & \text { Inducer } & \text { BADH } & \text { BZDH } & \text { C23O } & \text { HMSH } & \text { HMSD } & \text { C12O } \\ \text { MT53 } & m \text {-Xylene } & 175 & 390 & 1980 & 325 & 140 & <1 \\ & m \text {-Toluate } & 15 & 30 & 3450 & 220 & 80 & \text { ND } \\ & \text { None } & 30 & 30 & 96 & 11 & 10 & <1 \\ & \text { Benzoate } & \text { ND } & \text { ND } & \text { ND } & \text { ND } & \text { ND } & <1 \\ \text { MT53-1 } & m \text {-Xylene } & 30 & 4 & 4 & 2 & 2 & <1 \\ & m \text {-Toluate } & 14 & 13 & 140 & 88 & 30 & \text { ND } \\ & \text { None } & 20 & 10 & 6 & 2 & 1 & 10 \\ & \text { Benzoate } & \text { ND } & \text { ND } & \text { ND } & \text { ND } & \text { ND } & 59 \\ \text { MT53-2 } & m \text {-Xylene } & 12 & 6 & 9 & 2 & 1 & <1 \\ & m \text {-Toluate } & 13 & 8 & 150 & 88 & 25 & \text { ND } \\ & \text { None } & 16 & 7 & 10 & 2 & 2 & 9 \\ & \text { Benzoate } & \text { ND } & \text { ND } & \text { ND } & \text { ND } & \text { ND } & 70 \\ \text { MT53-3 } & m \text {-Xylene } & 10 & 3 & <1 & <1 & <1 & <1 \\ & m \text {-Toluate } & 4 & 5 & <1 & <1 & <1 & \text { ND } \\ & \text { None } & 8 & 3 & <1 & <1 & <1 & 10 \\ & \text { Benzoate } & \text { ND } & \text { ND } & \text { ND } & \text { ND } & \text { ND } & 180\end{array}$

sequential transfers in batch culture on benzoate-minimal medium or after $40-60 \mathrm{~h}$ in a simple chemostat with limiting benzoate, the populations were dominated by mutant strains which no longer grow on hydrocarbon substrates such as $m$-xylene $\left(\mathbf{M x y}^{-}\right)$but still grow on $m$-toluate $\left(\mathrm{Mtol}^{+}\right)$although more slowly than does wild-type MT53. Two such segregants, MT53-1 and MT53-2, independently isolated, were retained. As the cultures were continued, strains such as these diminished in number and the populations were taken over, eventually completely, by 
strains with the phenotype $\mathrm{Mxy}^{-} \mathrm{Mtol}^{-}$. These are typical of plasmid-free $P$. putida and this was confirmed experimentally by examining several for plasmid content: strain MT53-3 was retained for enzyme analysis as a typical plasmid-free segregant.

The probable reason for the sequential selection was differences in growth rates on benzoate. In batch cultures the approximate doubling times were found to be: MT53 (144 min), MT53-1 (102 min), MT53-3 (90 min).

\section{Enzyme analysis of segregants}

Enzyme assays (Table 2) show that MT53-1 and MT53-2 differ from wild-type MT53 in three main respects. (1) The specific activities of benzyl alcohol dehydrogenase $(x y l B)$ and benzaldehyde dehydrogenase $(x y l C)$ are not induced by $m$-xylene above the basal levels found in plasmid-free $P$. putida strains such as MT53-3. (2) The specific activities of catechol 2,3oxygenase $(x y l E)$, 2-hydroxymuconic semialdehyde hydrolase $(x y l F)$ and 2-hydroxymuconic semialdehyde dehydrogenase $(x y l G)$ in both induced and uninduced cells are lower than in MT53, but the ratio of induced : uninduced activities is about the same. (3) During growth on benzoate the chromosomally encoded catechol 1,2-oxygenase is induced.

\section{Plasmid analysis of segregants}

Both MT53-1 and MT53-2 contained plasmids (designated pWW53-1 and pWW53-2, respectively) which restriction digests showed were clearly derived from the wild-type plasmid by the deletion of about $30-35 \mathrm{kbp}$. The BamHI digests in particular were much simplified: in place of the 10 fragments of pWW53 (Keil et al., 1985a), pWW53-2 has only two large BamHI fragments and pWW53-1 has two large and one intermediate BamHI fragments. However this highlights a puzzling paradox. The RP4::pWW53 cointegrate plasmid pWW53-4, which carries the complete toluene/xylene catabolic pathway, has been the subject of detailed restriction analysis (Keil et al., 1987) and all the restriction fragments found in digests of pWW53 and which form part of the $36 \mathrm{kbp}$ insert of pWW53 DNA in pWW53-4 have been identified. Of the BamHI fragments, one (BC, see Fig. 4) carries genes of the meta pathway operon $(x y l D L E G F(I, J, K) H)$ and the regulatory genes $x y l R$ and $x y l S$. Two others (BE and BF) carry genes of the $x y l C A B$ operon. Yet these three fragments are missing from digests of both pWW53-1 and pWW53-2. The loss of $x y l C A B$ from both plasmids does not conflict with the enzyme assays (Table 2) since benzyl alcohol dehydrogenase $(x y l B)$ and benzaldehyde dehydrogenase $(x y l C)$ are not expressed, but both MT53-1 and MT53-2 grow on $m$-toluate and express the enzymes of the meta pathway operon. The loss of fragments BC and BD is, therefore, paradoxical.

\section{Molecular cloning of genes for catechol 2,3-oxygenase}

In the light of recent reports that some TOL plasmids encode two genes for catechol 2,3oxygenase ( $x y l E)$ (Keil et al., 1985b; Chatfield \& Williams, 1986) we attempted to clone fragments from plasmid preparations of $\mathrm{pWW} 53, \mathrm{pWW} 53-1$ and $\mathrm{pWW} 53-2$ which expressed catechol 2,3-oxygenase using the same procedure adopted by Chatfield \& Williams (1986). Ligating $X h o$ I digests of pWW53 into pKT230 resulted in eight recombinant plasmids which expressed catechol 2,3-oxygenase activity. Restriction mapping of these showed that three inserts were identical to the $2 \cdot 1 \mathrm{kbp}$ insert of pWW53-3555 obtained from pWW53-4 (Keil et al., $1985 a$ ) (Fig. $2 a$ ). The other five also had inserts of $2.1 \mathrm{kbp}$ but the configuration of restriction sites differed and did not correspond to any part of pWW53-4 (Fig. 2b).

When XhoI digests of pWW53-2 were ligated into pKT230, 17 transformants were found which expressed catechol 2,3-oxygenase and all of them had the same restriction map as the second type of fragment cloned from pWW53, the type not associated with pWW53-4 (Fig. $2 b$ ).

Thirteen $x y l E^{+}$transformants were obtained from $\mathrm{pWW} 53-1$. All were identical but differed from those isolated from pWW53 and pWW 53-2. They contained the BamHI site present in the insert from pWW 53-4 but the other restriction sites were identical to the fragment found only in pWW53-1 (Fig. 2c). 


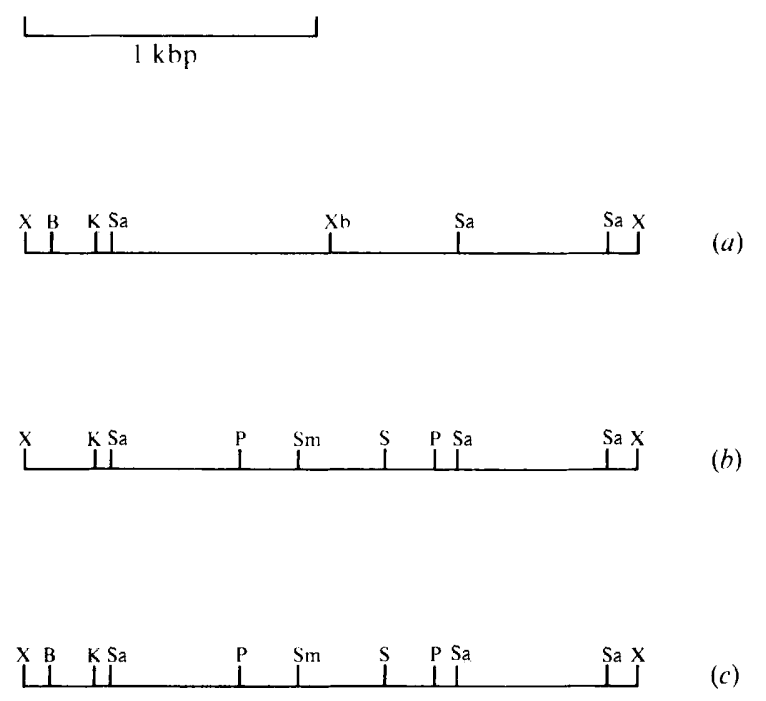

Fig. 2. Restriction maps of the small $X$ hoI fragments carrying catechol 2,3-oxygenase genes cloned from plasmids in Pseudomonas putida MT53 and its segregants. Fragments identical to both $(a)$ and $(b)$ were cloned from pWW 53 DNA. Only fragments identical to $(b)$ were cloned from pWW 53-2 DNA and only fragments identical to $(c)$ from pWW53-1. Abbreviations for restriction enzyme cutting sites: B, BamHI ; K, KpnI ; P, Pst I S, SstI; Sa, SalI ; Sm, SmaI ; X, XhoI; Xb, XbaI. In all cases where expression of the activity was strong transcription from the vector promoter was from left to right.

\section{Molecular cloning of large HindIII fragments}

pWW53 contains two large HindIII fragments, HA $(17.5 \mathrm{kbp})$ and $\mathrm{HB}$ (originally estimated to be $16.6 \mathrm{kbp}$ ) (Keil et al., 1985a). HA carries a complete meta pathway operon and forms part of the insert on pWW53-4 but is deleted in both pWW53-1 and pWW53-2. Both pWW53-1 and pWW53-2 each contain a single large HindIII fragment and Southern blotting showed that, when the cloned $X h o I$ fragments carrying the genes for catechol 2,3-oxygenase were used as probes against HindIII digests of the plasmids, these large fragments hybridized against the probes. Similar blots against digests of pWW53 indicated that HB might also hybridize but the poor resolution of $\mathrm{HA}$ and $\mathrm{HB}$ on gels made this a tentative conclusion only.

We therefore ligated HindIII digests of pWW53, pWW53-1 and pWW53-2 into pKT230 and screened $E$. coli transformants for the expression of catechol 2,3-oxygenase by spraying plates with $10 \mathrm{~mm}$-catechol.

From pWW53 DNA we obtained one transformant which contained an insert identical in its digestion with a range of endonucleases to the insert of pWW53-3301, carrying HA (Keil et al., $1985 a$ ). From another transformant we also obtained a second recombinant plasmid with a slightly smaller insert which had a different digestion pattern and corresponded to HB: the plasmid was named pWW53-3002.

Using the same method, we were also able to obtain the large HindIII fragments from each of pWW53-1 and pWW53-2 to give recombinants pWW53-3003 and pWW53-3004, respectively.

\section{Restriction mapping of $p W W 53-3002, p W W 53-3003$ and $p W W 53-3004$}

The three large HindIII inserts of pWW53-3002, pWW53-3003 and pWW53-3004 were mapped for cleavage sites for 11 restriction endonucleases by use of single, double and triple digestions of the plasmids and of subclones thereof: the maps are presented in Fig. 3 where they are compared with the published map for the HA insert of pWW53-3301 (Keil et al., 1985a). There is a clear relationship between the pattern of restriction sites on HA and HB. Of the 47 sites identified on HB, as many as 23 could be in apparently identical positions on HA, although 


$$
\text { . }
$$

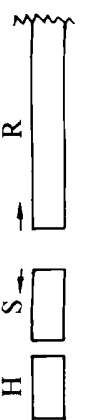

!

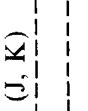

$\square^{1}$

$0 \square$

- $\square$

$-\square$

1-

-

=

$\underbrace{x}_{-\infty}$

I7-x

in- $-x$

㦴-

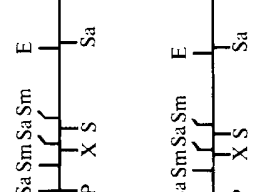

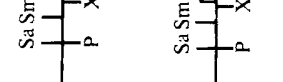

$n-10$

E-

E-

$-\infty$

-

$-\int_{-\infty}^{-\infty}$

$-1$

(1)

$\sum_{\substack{n \\ n}}^{3}$

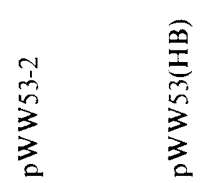

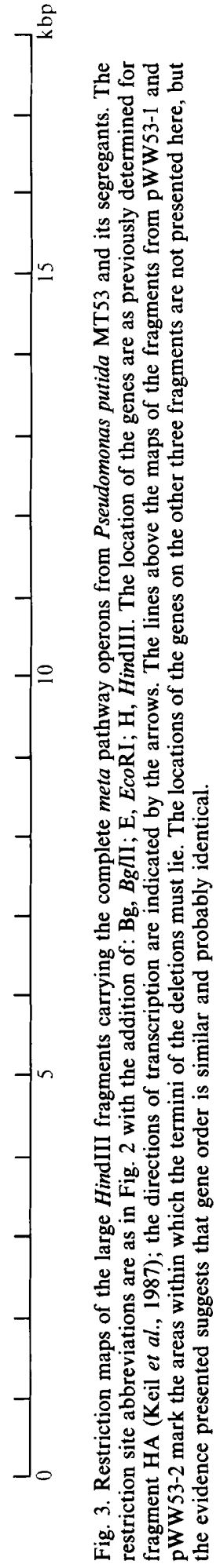


Table 3. Specific activity of catabolic enzymes in E. coli and P. putida strains carrying recombinant plasmids

Specific activities are expressed as milliunits (mg protein) $)^{-1}$. For abbreviations, see Table 1.

$\begin{array}{cllccc}\text { Plasmid } & \text { Host* } & \text { Inducer } & \text { C230 } & \text { HMSD } & \text { HMSH } \\ \text { pWW53-3301 } & \text { E. coli } & \text { None } & 36 & 1 & 0 \cdot 5 \\ & P \text {. putida } & \text { None } & 99 & 11 \cdot 5 & 14 \cdot 4 \\ & & m \text {-Toluate } & 1190 & 134 & 112 \\ \text { pWW53-3002 } & \text { E. coli } & \text { None } & 1 \cdot 3 & 0 \cdot 4 & <0 \cdot 1 \\ & P . \text { putida } & \text { None } & 20 & 9 \cdot 1 & 6 \cdot 6 \\ & & m \text {-Toluate } & 24 & 12 \cdot 8 & 5 \cdot 6 \\ \text { pWW53-3003 } & \text { E. coli } & \text { None } & 5 \cdot 2 & 0 \cdot 5 & <0 \cdot 1 \\ & \text { P. putida } & \text { None } & 22 & 8 \cdot 6 & 3 \cdot 1 \\ & & m \text {-Toluate } & 18 & 15 \cdot 8 & 7 \cdot 3 \\ \text { pWW53-3004 } & \text { E. coli } & \text { None } & 6 \cdot 9 & 0 \cdot 6 & <0 \cdot 1 \\ & P . \text { putida } & \text { None } & 19 & 7 \cdot 2 & 2 \cdot 7 \\ & & m \text {-Toluate } & 23 & 11 \cdot 3 & 4 \cdot 6 \\ \text { pWW53-3501 } & \text { E. coli } & \text { None } & 285 & \text { ND } & \text { ND } \\ \text { pWW53-3502 } & \text { E. coli } & \text { None } & 36 & \text { ND } & \text { ND } \\ \text { pWW53-3504 } & \text { E. coli } & \text { None } & 48 & \text { ND } & \text { ND }\end{array}$

* E. coli ED8654 or P. putida PaW130.

for this to be the case one has to allow for some slippage of alignment (of about 1-1.3 kbp) along the length of the cloned fragments. It is possible that this is the result of the accumulation of errors in the independent estimations of their sizes, but we think this is unlikely to account for slippage of that magnitude. If the size estimates of both are accurate, then an explanation could be the presence of small insertions in HA (or deletions in HB) causing the observed misalignment of restriction sites. The most obvious homology is at the beginning of the operons $(\mathrm{OP} 2, x y l D L)$; the apparent similarity is less in the middle of the operon but, allowing for the slippage, picks up again further downstream. However similarity is not apparent outside of the region of HA shown to carry the structural genes (Keil et al., 1987).

The two cloned HindIII fragments derived from the deletion plasmids pWW53-1 and pWW 53-2 were mapped by comparison of their digests with those of HA and HB to both of which they are clearly related. Both share a left-hand end with an identical configuration of sites to the left-hand end of HA but this changes to an order of sites identical to that of HB; this occurs at around coordinate 5 for pWW53-3003 and coordinate 3 for pWW53-3004. In pWW53-3003, the cross-over point occurs within the $2 \cdot 1 \mathrm{kbp} X$ hoI fragment shown to carry the catechol 2,3oxygenase gene confirming the data of Fig. 2.

It is clear from this that the deletions in pWW53-1 and pWW53-2 were formed by recombinational cross-over between homologous regions on fragments $\mathrm{HA}$ and $\mathrm{HB}$ giving rise to the novel HindIII fragments shown in Fig. 3.

\section{Functional analysis of $p W W 53-3002, p W W 53-3003$ and $p W W 53-3004$}

When mobilized into plasmid-free $P$. putida $\mathrm{PaW} 130$, all three recombinant plasmids supported growth on minimal agar plates containing $m$-toluate, although at a substantially slower rate than did pWW53-3301 with its HA insert. The expression of three meta pathway enzymes, catechol 2,3-oxygenase, 2-hydroxymuconic semialdehyde hydrolase $(x y l F)$ and 2-hydroxymuconic semialdehyde dehydrogenase $(x y l G)$ by both $E$. coli and Pseudomonas host strains was confirmed but, compared with pWW53-3301, the uninduced activities were lower and were not induced by growth in the presence of $m$-toluate (Table 3). Compared with the specific activities in PaW696 carrying the plasmid with the HA insert, the uninduced levels of all three enzymes assayed were considerably lower and in the case of 2-hydroxymuconic semialdehyde hydrolase could not be detected in $E$. coli. This correlates with the poorer growth 


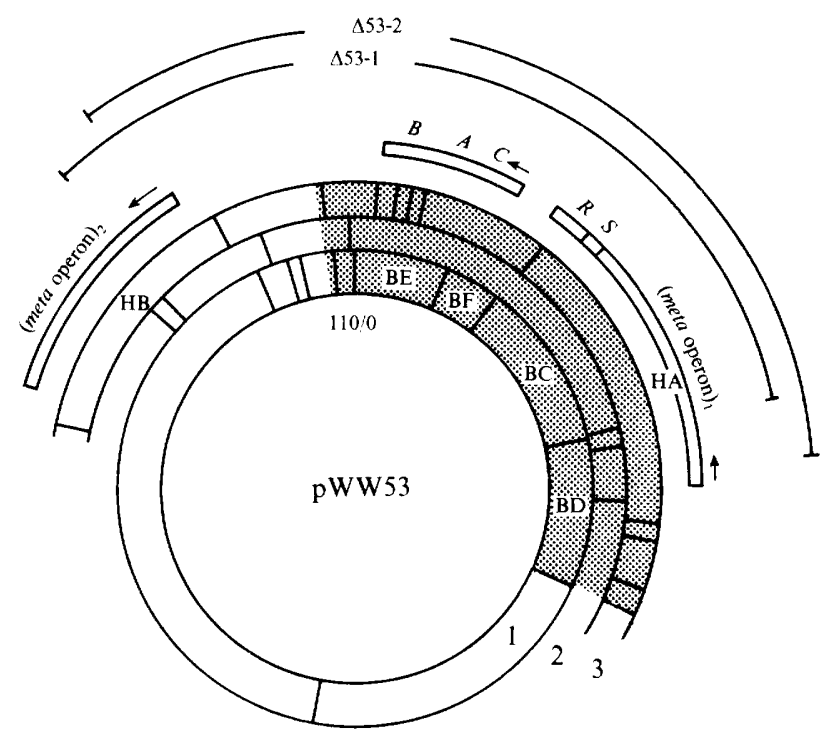

Fig. 4. Complete BamHI (1) map of pWW53 and partial KpnI (2) and HindIII (3) maps of the relevant region of the plasmid, showing the relative location of the catabolic genes on the plasmid. The fragments mentioned in the text are lettered appropriately. The directions of transcription are indicated by the arrows. The extent of the deletions in pWW 53-1 and pWW53-2 are indicated above the map. The shaded area represents the extent of pWW53 DNA found inserted in RP4 in the cointegrate plasmid pWW53-4 (Keil et al., 1987).

rates on $m$-toluate and also with the lower activities expressed from the parental plasmids, pWW53-1 and pWW53-2 (Table 2).

The ability of $P$. putida carrying pWW53-3002 to grow on $m$-toluate does not definitively prove the presence of the complete operon on HB since there are the ben genes, isofunctional to $x y l D$ (for benzoate dioxygenase) and $x y l L$ (for benzoate cis-diol dehydrogenase), which are chromosomally encoded, being part of the pathway for benzoate dissimilation. We confirmed the presence of $x y l L$ on HB by mobilizing pWW53-3002 into PaW95, a plasmid-free mutant lacking the chromosomal benzoate cis-diol dehydrogenase and which is unable to grow on benzoate. Mobilization of pWW53-3002 into PaW95 restored its ability to grow on benzoate. The joint presence of $x y l D L$ was demonstrated by subcloning the $S m a$ I fragment from the lefthand end of HB into pKT230 to generate pWW53-3901. E. coli cells containing pWW53-3901 were able to convert $m$-toluate to 3 -methylcatechol as demonstrated by the accumulation of a dark brown material, the autoxidation products of 3-methylcatechol, when plated onto Isosensitest agar containing $5 \mathrm{~mm}-m$-toluate.

\section{Relative locations of the TOL pathway genes on $p W W 53$}

A complete restriction map of pWW53 has only been determined for the BamHI fragments (Fig. 4), although fairly complete maps have been derived for HindIII and KpnI sites (Pickup, 1984). We have used the complete BamHI map to determine exactly the relationship between the two meta pathway operons and the extent of the deletions in pWW53-1 and pWW53-2 (Fig. 4). As can be seen, the catabolic genes span some $50 \mathrm{kbp}$ of the $110 \mathrm{kbp}$ plasmid with the single $x y l C A B$ operon between the two $x y l D L E G F(I, J, K) H$ operons. These two operons run in the same direction and the deletions which occur in MT53-1 and MT53-2 start in two different positions in the HA operon, which we will refer to as $(x y l D L E G F(I, J, K) H)_{1}$, and extend to homologous positions in the operon on $\mathrm{HB}(x y l D L E G F(I, J, K) H)_{2}$. The deletion removes the upper pathway operon, $x y l C A B$, resulting in the $\mathrm{Mxy}^{-}$phenotype. 


\section{DISCUSSION}

Although two earlier papers have shown that some naturally occurring TOL plasmids contain two genes for catechol 2,3-oxygenase (Keil et al., 1985b; Chatfield \& Williams, 1986) this paper reports the first demonstration of a duplicate copy of a complete operon on a TOL plasmid. The only other such natural duplication in a catabolic plasmid which has been reported is the nylon oligomer plasmid pOAD2, which has been shown to carry both a functional nylB gene, encoding a 6-aminohexanoate linear dimer hydrolase, and a $n y l B^{\prime}$ gene which encodes a highly homologous protein with a much reduced hydrolase activity (Negoro et al., 1983, 1984). It is proposed that this gene and its duplicate copy are the result of relatively recent evolutionary events (Ohno, 1984).

In the case of pWW53 two events could have resulted in its present structure. Either the two operons are the result of a gene duplication event on the plasmid and have subsequently diverged by mutation to give the two distinguishable operons now present. Alternatively, a plasmid carrying a single meta pathway operon might have acquired a second by recombination with another TOL plasmid coexisting in the same cell or with chromosomally integrated TOL genes as have been described in two strains (Jeenes \& Williams, 1982; Sinclair et al., 1986). It is impossible to distinguish between these possibilities but the difference in the restriction maps between the two would seem to rule out a recent duplication event.

The coexistence of these two homologous copies has the consequence that recombination can occur between them giving rise to the deletions found in pWW53-1 and pWW53-2. Since a deletion of this type always gives rise to a $\mathrm{Mxy}^{-}$phenotype, it is relatively simple to recognize deletants. However, we have never found any during growth of MT53 on nonselective media. By that criterion the plasmid would seem to be stable. As seen for TOL plasmids, growth on benzoate appears to be a very strong selection against maintenance of the complete catabolic function. This has been attributed to an increased growth rate of the segregants on benzoate (Williams \& Murray, 1974; Williams et al., 1988), although this has been disputed (Stephens \& Dalton, 1987). In the case of MT53 the growth-rate hypothesis appears to be reasonable since the deletants grow measurably faster on benzoate than does the wild-type which they displace and then are themselves displaced by the even faster growing plasmid-free strains. The increased growth rate on benzoate of the deletants is paralleled by a reduction in growth rate on $m$-toluate. This is the result of much lower levels of expression of the meta pathway enzymes. It is presumed in the case of benzoate that these lower activities of the meta pathway enzymes cause some catechol to accumulate transiently in the medium, allowing cis, cis-muconate to form and thus inducing the chromosomal $\beta$-ketoadipate pathway, as indicated by the induction of catechol 1,2-oxygenase (Table 2). It is the use of this pathway which supports the higher growth rate (Williams et al., 1988). Since $m$-toluate and its metabolites cannot be utilized by the $\beta$ ketoadipate pathway or cause its induction there is no relief from the reduced specific activities of the meta pathway enzymes. The data are, therefore, consistent with benzoate acting as a strong selection for the amplification of a relatively small number of spontaneous deletants, as proposed for the archetype plasmid pWW0 where recombination occurs between two $1.4 \mathrm{kbp}$ direct repeats to delete the entire catabolic region (Bayley et al., 1977; Meulien et al., 1981).

It is interesting to note that both the regulatory genes which have been identified on pWW53-4, $x y l S$ and $x y l R$, are deleted in pWW53-1 and pWW53-2 and, yet, the meta pathway enzymes remain inducible, albeit to lower levels than from pWW53 itself. This shows that there remain on the deleted plasmids a regulatory gene or genes which can act at the operatorpromoter region of the operons which are formed as a hybrid between that on HA and that on HB. There does not appear to be a $x y l S$ gene downstream of the meta pathway operon on HB, as there is on HA, since there is no induction by $m$-toluate of the enzymes in $P$. putida strains carrying pWW53-3002, pWW53-3003 or pWW53-3004. In support of this, a probe prepared from the $x y l S$ region of $\mathrm{pWW} 0$, which does hybridize with the $x y l S$ on $\mathrm{HA}$, does not hybridize with $\mathrm{HB}$; it does, however, hybridize with two other regions of $\mathrm{pWW} 53$ (data not presented) one of which is retained in the deleted plasmids. We are currently investigating these two other homologous regions of the plasmid in order to ascertain whether there is a duplication of $x y l S$ as well as of the structural genes. 
What is not clear from the results presented here is whether both operons on $\mathrm{pWW} 53$ function equally in the catabolism of aromatic hydrocarbons by wild-type MT53. The indications are that $(x y l D L E G F(I, J, K) H)_{2}$ is probably of less significance than $(x y l D L E G F(I, J, K) H)_{1}$ because of the generally lower specific activities found on the deleted plasmids and from the cloned genes on HB. The reason for these lower levels of expression may be the result of some differences in regulation or could be intrinsic properties of the enzymes, such as increased Michaelis constants or reduced turnover numbers. Only further investigation will reveal any differences in regulation, but preliminary results, such as the activity of catechol 2,3-oxygenase specified by the recombinant plasmids carrying the small $X h o I$ inserts (Table 3), suggest that the enzymes encoded on HB may be intrinsically less active, perhaps by about an order of magnitude.

Comparison of the results presented here with those of Chatfield \& Williams (1986) would suggest that pWW53 is not unique in its possession of duplicate catabolic operons. The restriction maps of the two $X h o I$ fragments from pWW53 which carry $x y l E$ genes (Fig. 2) are identical with the maps of the two small XhoI fragments which Chatfield \& Williams showed were present on a number of newly isolated plasmids obtained from different geographical locations; the $x y l E^{+}$fragment from HA corresponds exactly with the gene referred to as coding for C23OIa and that on HB corresponds to the gene for C23OIb. The situation may be even more complex with other TOL plasmids since we have evidence that another plasmid, pWW15, that forms a range of deletion derivatives when grown on benzoate (Keil \& Williams, 1985) carries two homologous, yet distinguishable, $x y l C A B$ operons, and it is equivalent recombination between these regions of homology which result in the deletions (K. J. O'Donnell \& P. A. Williams, unpublished results).

The most intriguing question which arises from the coexistence of the two operons is whether such a plasmid has some particular selective advantage which accounts for its apparent stability and persistence. Three possibilities spring to mind: (1) some of the enzymes form mixed oligomers between the analogous gene products from the two operons which have some advantageous catalytic property or stability. (2) Recombination could take place between the two copies to repair major mutational damage to one of them such as has been proposed for the homologous genes for the two branches of the chromosomal $\beta$-ketoadipate pathway (Doten $e t$ al., 1987). (3) The regulation of the two operons differs such that they are expressed individually under different growth conditions. We are currently investigating these possibilities. The answers could give some interesting insights into the evolution of pathways and of plasmids.

We wish to thank Linda Shaw, Henry Keil and Susan Assinder for their helpful discussions during this investigation.

\section{REFERENCES}

Bagdasarian, M., LuRz, R., RÜCKert, B., Franklin, F. C. H., Bagdasarian, M. M., Frey, J. \& Timmis, K. N. (1981). Specific purpose plasmid cloning vectors. II. Broad host range, high copy number RSF1010-derived vectors and a host : vector system for gene cloning. Gene 16, 237-247.

Bayley, S. A., Duggleby, C. J., Worsey, M. J., Williams, P. A., Hardy, K. G. \& Broda, P. (1977). Two modes of loss of the Tol function from Pseudomonas putida mt-2. Molecular and General Genetics 154, 203-204.

Chatfield, L. K. \& Williams, P. A. (1986). Naturally occurring TOL plasmids in Pseudomonas strains carry either two homologous or two nonhomologous catechol 2,3-oxygenase genes. Journal of Bacteriology 168, 878-885.

Doten, R. C., GregG, L. A. \& ORnston, L. N. (1987). Influence of the cat $B C E$ sequence on the phenotypic reversion of a pcaE mutation in Acinetobacter calcoaceticus. Journal of Bacteriology 169, 3175-3180.
GrINTER, N. J. (1983). A broad host range cloning vector transposable to various replicons. Gene 21, 133-143.

Holmes, D. S. \& Quigley, M. (1981). A rapid boiling method for preparation of bacterial plasmids. Analytical Biochemistry 114, 193-197.

JeEnes, D. J. \& Williams, P. A. (1982). Excision and integration of degradative pathway genes from TOL plasmid pWW0. Journal of Bacteriology 150, 188194.

KeIL, H. \& Williams, P. A. (1985). A new class of TOL plasmid deletion mutants in Pseudomonas putida MT15 and their reversion by tandem gene amplification. Journal of General Microbiology 131, 1023-1033.

Keil, H., Keil, S., Pickup, R. W. \& Williams, P. A $(1985 a)$. Evolutionary conservation of genes coding for meta pathway enzymes within TOL plasmids pWW0 amd pWW53. Journal of Bacteriology 164, 887-895.

Keil, H., Lebens, M. R. \& Williams, P. A. (1985b). 
TOL plasmid PWW15 contains two nonhomologous, independently regulated catechol 2,3oxygenase genes. Journal of Bacteriology 163, 248255.

KeIl, H., Keil, S. \& Williams, P. A. (1987). Molecular analysis of regulatory and structural $x y /$ genes of the TOL plasmid pWW53-4. Journal of General Microbiology 133, 1149-1158.

Kunz, D. A. \& Chapman, P. J. (1981). Isolation and characterization of spontaneously occurring TOL plasmid mutants of Pseudomonas putida HS1. Journal of Bacteriology 146, 952-964.

Maniatis, T., Fritsch, E. F. \& SAMBroOK, J. (editors) (1982). Molecular Cloning : a Laboratory Manual, pp. 94-148. Cold Spring Harbor, New York: Cold Spring Harbor Laboratory.

Meulien, P., Downing, R. G. \& Broda, P. (1981) Excision of the $40 \mathrm{~kb}$ segment of the TOL plasmid from Pseudomonas putida $\mathrm{mt}-2$ involves direct repeats. Molecular and General Genetics 184, 97-101.

MURRay, K. \& Williams, P. A. (1974). Role of catechol and the methylcatechols as inducers of aromatic metabolism in Pseudomonas putida. Journal of Bacteriology 117, 1153-1157.

Murray, N. E., Brammar, W. J. \& Murray K. (1977). Lambdoid phages that simplify the recovery of in vitro recombinants. Molecular and General Genetics 150, 53-61.

Nakazawa, T., Hayashi, E., Yokota, T., Ebina, Y.\& NAKAZAWA, A. (1978). Isolation of TOL and RP4 recombinants by integrative suppression. Journal of Bacteriology 134, 270-277.

Negoro, S., Taniguchi, T., Kanaoka, M., Kimura, H. \& OKADA, H. (1983). Plasmid determined enzymatic degradation of nylon oligomers. Journal of Bacteriology 155, 22-31.

Negoro, S., Nakamura, S. \& OKada, H. (1984). DNA-DNA hybridization analysis of nylon oligomer-degradative plasmid pOAD2: identification of the DNA region analogous to the nylon oligomer degradation gene. Journal of Bacteriology 158, 419-424.

OHNo, S. (1984). Birth of a unique enzyme from an alternative reading frame of the preexisted, internally repetitious coding sequence. Proceedings of the National Academy of Sciences of the United States of America 81, 2421-2425.

PICKUP, R. W. (1984). Physical and structural properties of TOL plasmids in Pseudomonas. PhD thesis, University of Wales.
Sala-Trepat, J.-M. \& Evans, W. C. (1971). The meta cleavage of catechol by Azotobacter species: 4-oxalocrotonate pathway. European Journal of Biochemistry 20, 400-413.

Shaw, L. E. \& Williams, P. A. (1988). Physical and functional mapping of two cointegrate plasmids derived from RP4 and TOL plasmid pDK1. Journal of General Microbiology 134, 2463-2474.

Sinclair, M. I., MaXwell, P. C., Lyon, B. R. \& Holloway, B. W. (1986). Chromosomal location of TOL plasmid DNA in Pseudomonas putida. Journal of Bacteriology 168, 1302-1308.

SOUTHERN, E. M. (1975). Detection of specific sequences among DNA fragments separated by gel electrophoresis. Journal of Molecular Biology 98, 505-518.

Stephens, G. M. \& Dalton, H. (1987). The effect of lipophilic weak acids on the segregational stability of TOL plasmids in Pseudomonas putida. Journal of General Microbiology 133, 1891-1899.

WheAtcroft, R. \& Williams, P. A. (1981). Rapid methods for the study of both stable and unstable plasmids in Pseudomonas. Journal of General Microbiology 124, 433-437.

Williams, P. A. \& MURRay, K. (1974). Metabolism of benzoate and the methylbenzoates by Pseudomonas putida (arvilla) mt-2: evidence for the existence of a TOL plasmid. Journal of Bacteriology 120, 416-423.

Williams, P. A. \& Worsey, M. J. (1976). Ubiquity of plasmids in coding for toluene and xylene metabolism in soil bacteria: evidence for the existence of new TOL plasmids. Journal of Bacteriology 125, 818-828.

Williams, P. A., TaYlor, S. D. \& GibB, L. E. (1988). Loss of the toluene-xylene catabolic genes of TOL plasmid pWW0 during growth of Pseudomonas putida on benzoate is due to a selective growth advantage of 'cured' segregants. Journal of General Microbiology 134, 2039-2048.

Worsey, M. J. \& Williams, P. A. (1975). Metabolism of toluene and xylenes by Pseudomonas putida (arvilla) mt-2: evidence for a new function of the TOL plasmid. Journal of Bacteriology 124, 7-13.

Yano, K. \& Nishi, T., (1980). pKJ1, a naturally occurring conjugative plasmid coding for toluene degradation and resistance to streptomycin and sulphonamides. Journal of Bacteriology 143, 552-560. 